\title{
Colección de poemas
}

\author{
¡Madre! \\ ¡Madre!, tu dulce imagen \\ Santificada está en mi pensamiento, \\ $Y$ al verte y recordarte
}

Se enciende en luz de amor mi sentimiento.

Servirte de rodillas sería poco

Por lo mucho que te amo,

Pues tú me has dado la vida

$Y$ el saber lo que es vivir.

Si cien veces caigo,

Cien veces me levantas,

Si yo te olvido,

Tú no te olvidas de mí.

Si tú un día me dejas

$Y$ al cielo vas a vivir.

Dime: madre mía

¿Qué será de mí existir?

Mary Guerrero (1996) 


\section{¡Conexión celestial!}

Me pregunto: ¿Por qué estando tan lejos, te siento tan cerca?

¡Será acaso que tú corazón y el mío se conectan!

Esa luz proyectada por tus ojos

hace que mi razón y mi alma se desvanezcan

y cuando te siento lejos me entristezca...

Mary Guerrero (29/07/2019)

\section{¡Luna!}

Hermosa luna,

Déjame contemplar las estrellas,

Todas las noches vengo a buscar a la más bella,

Imaginándome por un instante que puede ser ella...

No seas envidiosa y brilles más que ella...

Ya es dificil buscarla en un millar de estrellas.

Mary Guerrero (09/03/2020) 


\section{¡Carta al cielo!}

Te escribiré una carta hasta el cielo

Aunque ya no te vea,

Aunque ya no me escuches,

Aunque ya desvanezca...

Pensaré que mis lágrimas

Serán tu respuesta

$Y$ el dulce silencio

Será una advertencia...

No me da igual tu ausencia,

Ahora pongo más atención al murmullo de la soledad.

Ahora todo tiene sentido...

Ahora sé cuánto quiero cobijarme con tus alas de ángel mamá...

Mary Guerrero (16/03/2020) 